\title{
DESIGN OF OBSERVER OF FLUX LINKAGE OF SYNCHRONOUS DRIVE OF ROLLING MILL
}

\author{
I.R. Abdulveleev*, T.R. Khramshin, G.P. Kornilov, A.A. Nikolaev \\ Nosov Magnitogorsk State Technical University, Magnitogorsk, Russian Federation \\ *leggyild@mail.ru
}

\begin{abstract}
The paper considers the design of control system for variable-frequency synchronous drive with vector torque control. Such drives are used in units with enough wide speed range and shock loading, for example, hot and cold rolling mills. Two coordinates generate the torque of the systems under consideration: current and flux linkage of the stator. This paper provides parameter calculation for the observer of flux linkage state of the stator of synchronous motor with damper windings. The system is implemented based on the Luenberger observer with error-feedback. Flux linkage is determined within the orthogonal coordinate system $d, q$ rotating synchronously with the rotor. The complex of a synchronous exited motor and state observer has been modeled. Modeling results demonstrate that a fractional error of flux linkage generation does not exceed $0.15 \%$.

Keywords: Common Luenberger state observer, stator flux linkage, synchronous motor with damper windings, electric drive of rolling mills.
\end{abstract}

\section{Introduction}

Variable frequency synchronous motors (SM) with the vector control of electromagnetic torque are used at main electric drives of the rolling mills [1-3]. It prevents motor dropout of synchronism and allows motor thrust operation as at DC electric drive at overloads in the torque-limiting mode.

As vector control implies operation in coordinates oriented according to one of the magnetic flux linkage, the SM control system may be designed on the orthogonal coordinate axes of the stator $(\alpha, \beta)$ or rotor $(d, q)$. As a rule, control is implemented for the simplification purpose as a system rotating together with the controlled vector, namely, the $d, q$ system. Consequently, this approach enables vector control due to regulation of scalar values of its projection of the coordinate axes. In this case, the torque control may be represented with the formula:

$$
M=\frac{3}{2} Z_{p}\left(\psi_{d} i_{q}-\psi_{q} i_{d}\right)
$$

A significant disadvantage of this method is the need for controlling all four changing values, which complicates the control system. As a solution of this issue, a rotating coordinate system $m, l$ is proposed in [4], which axis $m$ is oriented in the direction of the flux linkage vector of the stator $\bar{\psi}_{s}$, while the stator current projection $i_{l}$ is put on axis $l$. Switching to a new coordinate system helps preventing consumption of reactive power in the synchronous machine by means of excitation field control. Against this background, the stator current $\bar{l}_{l}$ being orthogonal to the flux linkage $\bar{\psi}_{S}$ coincides with the stator voltage vector. Therefore, the torque control is reduced to scalar regulation of the stator flux linkage $\psi_{s}$ and projection of the stator current $i_{l}$, which form is similar to control of the DC motor current:

$$
M=\frac{3}{2} Z_{p} \psi_{s} i_{l} \text {. }
$$

The equation (2) provides for separate SM torque control - by the flux linkage and stator current.

Relying on the required torque, the control system generates stator current setting, which specifies the stator voltage vector with current controller and corresponding coordinate transformations. Then, the inverter of the frequency converter generates this vector by means of pulse-width modulation.

The main problem at implementation of this approach is complexity of measuring stator flux linkage $\bar{\psi}_{s}$ required for calculation of the SM internal angle. Strict dynamic requirements to electric drives of the rolling mills cannot be met without quick-response feedbacks according to coordinates unavailable for direct measuring. Under these conditions, the use of state observer appears to be rather promising, because it provides estimate of unknown value according to the known motor coordinates (current, voltage and rotation rate). The methods of observer selection and setting for asynchronous motors are thoroughly studied and proposed by foreign and domestic researchers [5-7]. The issues of observer computing for the synchronous motor with a salient-pole rotor and damper windings have not been practically covered.

\section{Observer of magnetic field state \\ of synchronous motor stator}

The authors of this paper offer description of state observer of magnetic flux linkage of the stator of synchronous motor based on the Luenberger observer with error-feedback.

Two main principles are generally applied at implementation of the state observers for asynchronous motors (AM): observer with sensors (current meter and angular position encoder of the rotor) and sensorless observer (measuring current and voltage) [8, 9]. In the first case, when designing observer, a mathe- 
matical model of dynamic equilibrium of the AM rotor based on the rotor current is only used:

$$
\left\{\begin{array}{c}
0=\frac{d \psi_{r d}}{d t}+I_{r d} R_{r} \\
0=I_{r d} R_{r}+\Delta \omega \psi_{r d}
\end{array}\right.
$$

Here, observer parameters are computed with due regard to active resistance of the rotor assumed to be constant. However, during operation under dynamic overloads, the rotor winding is greatly heated; its active resistance rises. Consequently, observer functioning under severe motor operation conditions cannot be appropriately because of changed initial design parameters. A solution of this matter is designing complex adaptive state observers.

When designing a sensorless observer, the value of angular rate of the rotor is calculated with mathematical method; the equation of dynamic AM equilibrium based on the stator voltage is used together with (3):

$$
\left\{\begin{array}{l}
U_{s \alpha}=\frac{d \psi_{s \alpha}}{d t}+I_{s \alpha} R_{s} \\
U_{s \beta}=\frac{d \psi_{s \beta}}{d t}+I_{s \beta} R_{s} .
\end{array}\right.
$$

A shortage of this method is the need for integration of differences $\left(U_{s \alpha}-I_{s \alpha} R_{s}\right)$ and $\left(U_{s \beta}-I_{s \beta} R_{s}\right)$ at determining projections of the stator flux linkage. As the value of active resistance of high power machine stator is extremely negligible, voltage drop at the stator is also low; hence, integration of variables upon availability of DC components may ultimately cause the system integral saturation.

To eliminate the above drawbacks of the observer of powerful SMs of the rolling mill, the proposed approach combines positive properties of the aforementioned principles. Accordingly, stator flux linkage is calculated with mathematical models of a synchronous machine reflecting its current and voltage and without notice of a non-linear nature of the magnetic system. The rotor rotation rate is supposed to be a known measurable value; the state observer is believed to be tolerant to its change.

\section{Luenberger observer}

The mathematical model of continuous linearcontrolled stationary entity with many inputs and outputs is presented in a standard (5) and transformed (6) view:

$$
\left\{\begin{array}{c}
\dot{x}=A x+B u \\
y=C x
\end{array}\right.
$$

where $\boldsymbol{u}$ - multidimensional vector of control actions $(r \times 1)$;

$\boldsymbol{y}$ - measurable $m$-dimensional output $(m \times n)$;

$\boldsymbol{x}$ - variables setting the system within the state space $(n \times 1)$;

$\boldsymbol{A}(n \times n), \boldsymbol{B}(n \times r), \boldsymbol{C}(m \times n)-$ constant matrices.

$\left[\begin{array}{l}\dot{x}_{1} \\ \dot{x}_{2}\end{array}\right]=\left[\begin{array}{ll}A_{11} & A_{12} \\ A_{21} & A_{22}\end{array}\right] \cdot\left[\begin{array}{l}x_{1} \\ x_{2}\end{array}\right]+\left[\begin{array}{l}B_{1} \\ B_{2}\end{array}\right] \cdot u$

$$
y=\left[\begin{array}{ll}
0 & I
\end{array}\right] \cdot\left[\begin{array}{l}
x_{1} \\
x_{2}
\end{array}\right]=x_{2},
$$

where $x_{1}-n$-dimension vector $((n-m) \times 1)$, for which an observer is designed; синхронного электропривода прокатного стана

$\boldsymbol{x}_{\mathbf{2}}$ - measurable $m$-dimensional vector $(m \times 1)$;

$\boldsymbol{I}$ - identity matrix $(m \times m)$.

Expression (6) may be written as an equation system:

$\left\{\dot{x}_{1}=A_{11} x_{1}+A_{12} x_{2}+B_{1} u\right.$

$\left\{\dot{x}_{2}=A_{21} x_{1}+A_{22} x_{2}+B_{2} u\right.$.

According to Luenberger [10], this equation system is reduced to the observer of the following type:

$$
\dot{\hat{x}}_{1}=A_{11} \hat{x}_{1}+A_{12} x_{2}+B_{1} u-K A_{21}\left(\hat{x}_{1}-x_{1}\right)
$$

where $\hat{\boldsymbol{x}}_{\mathbf{1}}-$ considered vector $\boldsymbol{x}_{1}$;

$\boldsymbol{K}$ - coefficient matrix.

Equation (8) enables deriving a formula for error calculation:

$$
\dot{\tilde{x}}_{1}=\dot{\hat{x}}_{1}-\dot{x}_{1}=\left(A_{11}-K A_{21}\right) \tilde{x}_{1} \text {. }
$$

The use of the Luenberger observer to deduce flux linkage of the synchronous machine stator to be considered below shows that error calculation does not involve a critical difficulty, because matrix elements $\boldsymbol{A}_{\mathbf{1 1}}$ and $\boldsymbol{A}_{\mathbf{2 1}}$ varydepending on the rotor rate $\omega_{r}$ having a real value. Coefficients $\boldsymbol{K}$ shall be selected in such a manner as to have eigenvalues of the matrix $\left(\boldsymbol{A}_{11}-\boldsymbol{K} \boldsymbol{A}_{21}\right)$ in the left portion of the complex plane to provide a stable nature of the transient process.

Then, the observer of vector $\boldsymbol{x}_{\mathbf{1}}$ with error forecasting according to the feedback may take the following form [10]:

$$
\begin{aligned}
& \dot{\hat{x}}_{1}=A_{11} \hat{x}_{1}+A_{12} x_{2}+B_{1} u-K(\hat{z}-z)= \\
& =A_{11} \hat{x}_{1}+A_{12} x_{2}+B_{1} u- \\
& -K\left(A_{21} \hat{x}_{1}-\dot{y}+A_{22} x_{2}+B_{2} u\right)= \\
& =\left(A_{11}-K A_{21}\right) \hat{x}_{1}+\left(A_{12}-K A_{22}\right) x_{2}+ \\
& +\left(B_{1}-K B_{2}\right) u+K \dot{y} .
\end{aligned}
$$

This observer contains a derivative of output values, which is undesirable because it results in intensification of distortions present in initial signals. There under, the derivative is replaced with a dummy variable:

$$
\varepsilon=\widehat{x}_{1}-K y \text {. }
$$

When combining (10) and (11), a final observer formula may be written as the following equation system:

$$
\left\{\begin{array}{c}
\dot{\boldsymbol{\varepsilon}}=\left(A_{11}-K A_{21}\right) \varepsilon+\left[\left(A_{12}-K A_{22}\right)+\right. \\
\left.+\left(A_{11}-K A_{21}\right) K\right] y+\left(B_{1}-K B_{2}\right) u \\
\hat{x}_{1}=\varepsilon+K y .
\end{array}\right.
$$

The structural diagram of the reduced-order Luenberger observer with feedback is shown in Fig. 1.

\section{Observer of current and flux linkage of SM stator}

Equations of SM voltage equation shall be written as follows:

$$
\left\{\begin{array}{c}
u_{d}=p \psi_{d}-\omega_{r} \psi_{q}+R_{a} i_{d} ; \\
u_{q}=p \psi_{q}-\omega_{r} \psi_{d}+R_{a} i_{q} ; \\
0=p \psi_{y d}+R_{y d} i_{y d} ; \\
0=p \psi_{y q}+R_{y q} i_{y q} ; \\
u_{f}=p \psi_{f}+R_{f} i_{f} ;
\end{array}\right.
$$




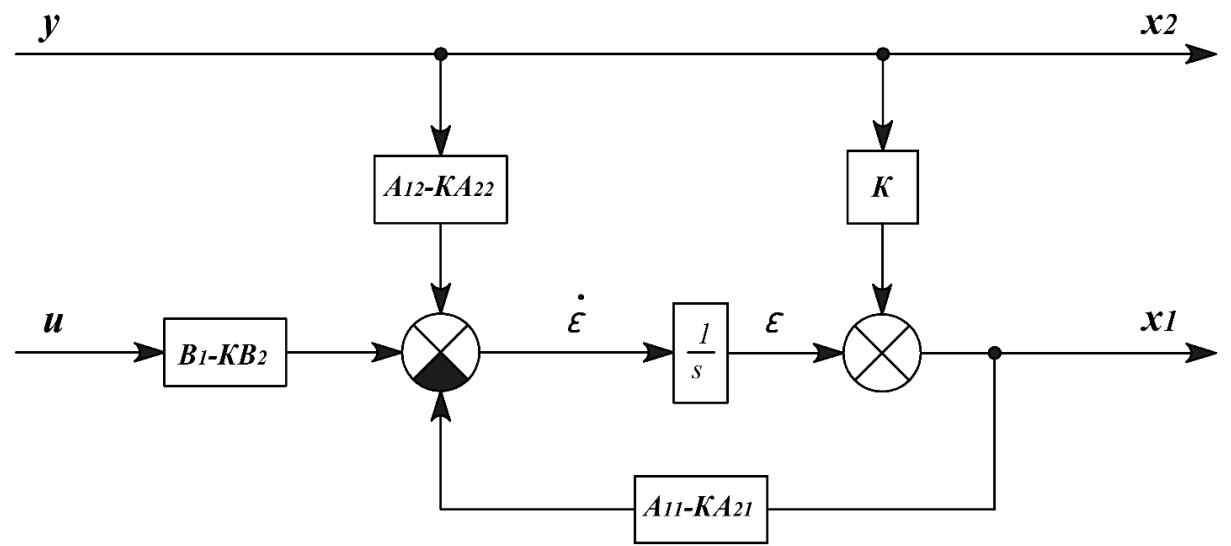

Fig. 1. Luenberger observer

The following non-observable and unmeasurable parameters shall be excluded from this equation system: $\psi_{y d}$, $\psi_{y q}, \psi_{f}, i_{y d}, i_{y q}$. At a later stage, they may be determined with the known current values $i_{d}, i_{q}, i_{f}$ and observable projections of stator flux linkage $\psi_{d}, \psi_{q}$. Such transformations are enabled with the current equations for flux linkages of synchronous machine windings:

$$
\left\{\begin{array}{c}
\psi_{d}=L_{d} i_{d}+L_{a d} i_{y d}+L_{a d} i_{f} ; \\
\psi_{q}=L_{q} i_{q}+L_{a q} i_{y q} ; \\
\psi_{y d}=L_{a d} i_{d}+L_{y d} i_{y d}+L_{a d} i_{f} ; \\
\psi_{y q}=L_{a q} i_{q}+L_{y q} i_{y q} ; \\
\psi_{f}=L_{a d} i_{d}+L_{a d} i_{y d}+L_{f} i_{f} ;
\end{array}\right.
$$

where $L_{d}=L_{a d}+L_{\sigma a} ; L_{q}=L_{a q}+L_{\sigma a} ; L_{y d}=L_{a d}+L_{\sigma y d} ; L_{y q}=L_{a q}+L_{\sigma y q} ; L_{f}=L_{a d}+L_{\sigma f}$.

Due to this replacement, the equation (13) will take the following form:

$$
\left\{\begin{array}{c}
u_{d}=p \psi_{d}-\omega_{r} \psi_{q}+R_{a} i_{d} \\
u_{q}=p \psi_{q}-\omega_{r} \psi_{d}+R_{a} i_{q} \\
0=-p \psi_{d}+\left(L_{\sigma a}+\frac{L_{a d} L_{\sigma y d}}{L_{y d}}\right) p i_{d}+\frac{L_{a d} L_{\sigma y d}}{L_{y d}} p i_{f}-\frac{R_{y d}}{L_{y d}} \psi_{d}+\frac{L_{d} R_{y d}}{L_{y d}} i_{d}+\frac{L_{a d} R_{y d}}{L_{y d}} i_{f} \\
0=-p \psi_{q}+\left(L_{\sigma a}+\frac{L_{a q} L_{\sigma y q}}{L_{y q}}\right) p i_{q}-\frac{R_{y q}}{L_{y q}} \psi_{q}+\frac{L_{q} R_{y q}}{L_{y q}} i_{q} \\
u_{f}=p \psi_{d}-L_{\sigma a} p i_{d}+L_{\sigma f} p i_{f}+R_{f} i_{f}
\end{array}\right.
$$

Expression (15) shall be presented in a matrix form:

$$
\begin{aligned}
& {\left[\begin{array}{c}
u_{d} \\
u_{q} \\
0 \\
0 \\
u_{f}
\end{array}\right]=\left[\begin{array}{ccccc}
1 & 0 & 0 & 0 & 0 \\
0 & 1 & 0 & 0 & 0 \\
-1 & 0 & L_{\sigma a}+\frac{L_{a d} L_{\sigma y d}}{L_{y d}} & 0 & \frac{L_{a d} L_{\sigma y d}}{L_{y d}} \\
0 & -1 & 0 & L_{\sigma a}+\frac{L_{a q} L_{\sigma y q}}{L_{y q}} & 0 \\
1 & 0 & -L_{\sigma a} & 0 & L_{\sigma f}
\end{array}\right] \times} \\
& \times p\left[\begin{array}{c}
\Psi_{d} \\
\Psi_{q} \\
i_{d} \\
i_{q} \\
i_{f}
\end{array}\right]+\left[\begin{array}{ccccc}
0 & -\omega_{r} & R_{a} & 0 & 0 \\
\omega_{r} & 0 & 0 & \mathrm{R}_{a} & 0 \\
-\frac{R_{y d}}{L_{y d}} & 0 & \frac{L_{d} R_{y d}}{L_{y d}} & 0 & \frac{L_{a d} R_{y d}}{L_{y d}} \\
0 & -\frac{R_{y q}}{L_{y q}} & 0 & \frac{L_{q} R_{y q}}{L_{y q}} & 0 \\
0 & 0 & 0 & 0 & R_{f}
\end{array}\right] \cdot\left[\begin{array}{c}
\Psi_{d} \\
\psi_{q} \\
i_{d} \\
i_{q} \\
i_{f}
\end{array}\right] .
\end{aligned}
$$
where

$$
\begin{aligned}
& \boldsymbol{x}_{\mathbf{1}}=\left[\begin{array}{l}
\Psi_{d} \\
\Psi_{q}
\end{array}\right] ; \quad \boldsymbol{x}_{\mathbf{2}}=\left[\begin{array}{l}
i_{d} \\
i_{q} \\
i_{f}
\end{array}\right] ; \quad \boldsymbol{u}=\left[\begin{array}{l}
u_{d} \\
u_{q} \\
u_{f}
\end{array}\right] \\
& \boldsymbol{A}_{\mathbf{1 1}}=\left[\begin{array}{cc}
0 & -\omega_{r} \\
\omega_{r} & 0
\end{array}\right] ; \quad \boldsymbol{A}_{\mathbf{1 2}}=\left[\begin{array}{ccc}
-R_{a} & 0 & 0 \\
0 & -R_{a} & 0
\end{array}\right]
\end{aligned}
$$




$$
\begin{aligned}
& \boldsymbol{A}_{\mathbf{2 1}}=\left[\begin{array}{cc}
\frac{L_{\sigma f} R_{y d}}{D} & \frac{\omega_{r}\left(L_{a d} L_{\sigma y d}+L_{\sigma f} L_{y d}\right)}{D} \\
-\frac{\omega_{r} L_{y q}}{Q} & \frac{R_{y q}}{Q} \\
\frac{L_{\sigma a} R_{y d}}{D} & -\frac{\omega_{r} L_{a d} L_{\sigma y d}}{D}
\end{array}\right] ; \\
& \boldsymbol{A}_{\mathbf{2 2}}=\left[\begin{array}{ccc}
-\frac{R_{a}\left(L_{a d} L_{\sigma y d}+L_{\sigma f} L_{y d}\right)+R_{y d} L_{d} L_{\sigma f}}{D} & 0 & -\frac{L_{a d}\left(R_{y d} L_{\sigma f}-R_{f} L_{\sigma y d}\right)}{D} \\
0 & -\frac{R_{a} L_{y q}+L_{q} R_{y q}}{Q} & 0 \\
-\frac{\left(-R_{a} L_{a d} L_{\sigma y d}+R_{y d} L_{d} L_{\sigma a}\right)}{D} & 0 & -\frac{R_{f}\left(L_{a d} L_{\sigma y d}+L_{\sigma a} L_{y d}\right)+R_{y d} L_{a d} L_{\sigma a}}{D}
\end{array}\right] \text {; } \\
& \boldsymbol{B}_{1}=\left[\begin{array}{lll}
1 & 0 & 0 \\
0 & 1 & 0
\end{array}\right] \text {; } \\
& \boldsymbol{B}_{2}=\left[\begin{array}{ccc}
\frac{L_{a d} L_{\sigma y d}+L_{\sigma f} L_{y d}}{D} & 0 & -\frac{L_{a d} L_{\sigma y d}}{D} \\
0 & \frac{L_{y q}}{Q} & 0 \\
-\frac{L_{a d} L_{\sigma y d}}{D} & 0 & \frac{L_{a d} L_{\sigma y d}+L_{\sigma a} L_{y d}}{D}
\end{array}\right] \\
& D=\left(L_{\sigma a} L_{y d}+L_{a d} L_{\sigma y d}\right) L_{\sigma f}+L_{a d} L_{\sigma y d} L_{\sigma a} ; \\
& Q=L_{a q} L_{\sigma y q}+L_{y q} L_{\sigma a} \text {. }
\end{aligned}
$$

\section{Observer parameter calculation}

This calculation was performed for a real synchronous motor of the cold rolling mill, which parameters are provided in Table 1.

Table 1

Parameters of SM of rolling mill

\begin{tabular}{|l|l|}
\hline$U=2.990 \mathrm{~V}$ & $L_{\sigma a}=0.891 \mathrm{mH}$ \\
\hline$I_{a}=1.570 \mathrm{~A}$ & $L_{\sigma v d}=1.1 \mathrm{mH}$ \\
\hline$f=19.25 \mathrm{~Hz}$ & $L_{\sigma y q}=1.2 \mathrm{mH}$ \\
\hline$Z_{p}=3$ & $L_{\sigma f}=1.4 \mathrm{mH}$ \\
\hline$J=1.810 \mathrm{~kg} \cdot \mathrm{m}^{2}$ & $L_{v d}=17.7 \mathrm{mH}$ \\
\hline$R_{a}=0.0115 \mathrm{Ohm}$ & $L_{y q}=7.4 \mathrm{mH}$ \\
\hline$R_{y d}=0.1198 \mathrm{Ohm}$ & $L_{d}=18.6 \mathrm{mH}$ \\
\hline$R_{y q}=0.0456 \mathrm{Ohm}$ & $L_{q}=8.3 \mathrm{mH}$ \\
\hline$R_{f}=0.0348 \mathrm{Ohm}$ & $\omega_{r . \text { rated }}=120.95 \mathrm{rad} / \mathrm{s}$ \\
\hline
\end{tabular}

Calculation of observer parameters is in deduction of coefficients in the matrix $\left(\boldsymbol{A}_{11}-\boldsymbol{K} \boldsymbol{A}_{\mathbf{2 1}}\right)$ determining drive dynamics, where $\boldsymbol{K}$ has the following form:

$$
\boldsymbol{K}=\left[\begin{array}{lll}
k_{11} & k_{12} & k_{13} \\
k_{21} & k_{22} & k_{23}
\end{array}\right] \text {. }
$$

The last formula, using known values of matrix elements $\boldsymbol{A}_{\mathbf{1 1}}$ and $\boldsymbol{A}_{\mathbf{2 1}}$, could be presented in expanded form:

$$
\left[\begin{array}{cc}
-2254.6 \cdot k_{11}+514.28 \cdot \omega_{r} \cdot k_{12}-1425.5 \cdot k_{13} & -\omega_{r}-673.33 \cdot \omega_{r} \cdot k_{11}-2458.1 \cdot k_{12}+283.97 \omega_{r} \cdot k_{13} \\
\omega_{r}-2254.6 \cdot k_{21}+514.28 \cdot \omega_{r} \cdot k_{22}-1425.5 \cdot k_{23} & -673.33 \cdot \omega_{r} \cdot k_{21}-2458.1 \cdot k_{22}+283.97 \omega_{r} \cdot k_{23}
\end{array}\right] .
$$

As an observer being robust to variations of the rotation rate within the operating speed range is needed, coefficients $\mathrm{k}_{12}, k_{13}, k_{21}, k_{23}$ are taken to be equal to zero [11]. It enables weakening influence of the rotor rotation rate $\omega_{r}$ on observer functioning. As a result, we obtain a characteristic equation for determination of design coefficients $k_{11}, k_{12}$ :

$$
\begin{aligned}
& \operatorname{det}\left[s \boldsymbol{I}-\left(\boldsymbol{A}_{\mathbf{1 1}}-\boldsymbol{K} \boldsymbol{A}_{\mathbf{2 1}}\right)\right]=s^{2}+s\left(2254.6 \cdot k_{11}+2458.1 \cdot k_{22}\right)+ \\
& +\omega_{r}^{2}(1-673.33) \cdot(1-514.28)+2254.6 \cdot k_{11} \cdot 2458.1 \cdot k_{22}=0 .
\end{aligned}
$$

In such a way, the expression (18) takes a conventional form of quadratic equation:

$$
s^{2}+a s+\omega_{r}^{2} b+c=0,
$$

where

$$
\begin{aligned}
& a=2254.6 \cdot k_{11}+2458.1 \cdot k_{22} ; \\
& b=\left(1-673.33 \cdot k_{11}\right) \cdot\left(1-514.28 \cdot k_{22}\right) \\
& c=2254.6 \cdot k_{11} \cdot 2458.1 \cdot k_{22} .
\end{aligned}
$$


Coefficients $k_{11}, k_{22}$ may be easily computed for roots of the quadratic equation with a negative real part under conditions $a>0$ and $\omega_{r}^{2} b+c>0$. As $\omega_{r}^{2} b$ is the only variable in the equation (19), change of coefficients (observer eigenvalues) at variable speeds may be estimated according to distribution of transfer function roots

$$
\frac{\omega_{r}^{2} b}{s^{2}+a s+c} \text {. }
$$

The observer has a rather high immunity at speed changes within a wide range both at real and complex conjugate roots of the characteristic equation. A stabilized speed control loop is an essential pre-requisite for powerful electric drives of the rolling mills [11].

Based on the belief that response speed of the observer shall exceed that of the system, real roots of the characteristic equation for case $\omega_{r}=0$ are assumed to be located in the left-hand semi-plane at point 1,000 . This root distribution corresponds to the following coefficient matrix:

$$
\boldsymbol{K}=\left[\begin{array}{ccc}
0,444 & 0 & 0 \\
0 & 0,407 & 0
\end{array}\right]
$$

With rising $\left|\omega_{r}\right|$, roots obtain an imaginary component; they are arranged at points $-707.1 \pm j 707.1$ on a complex plane. Variations of parameters $k_{11}, k_{12}$ of the coefficient depending on the rotor rotation rate are offered in Table 2 and Fig. 2; here, the rated rotation rate $\omega_{\text {r.rated }}=120.95 \mathrm{rad} / \mathrm{s}$ is taken as a basic value.

\section{Modeling results}

At the investigations performed, the proposed observer of flux linkage rate was integrated into a mathematical model of the cold rolling mill SM. The motor is represented with complete SM equations in transient processes and provides for change of main engineering coordinates - the static torque. At the model output, main motor coordinates are computed, namely - currents $\left(i_{d}, i_{q}, i_{f}\right)$, voltages $\left(u_{d}, u_{q}, u_{f}\right)$ and rotor rotation rate $\left(\omega_{r}\right)$. The observer is based on the above mathematical provisions and structural diagram in Fig. 1. Controller parameters comply with data in Table 2. The model was implemented with the MATLAB Simulink software.

Modeling results are shown in Fig. 3 at acceleration and load rise (changes of torque and rotation rate

Table 2

Observer coefficients

\begin{tabular}{|c|c|c|}
\hline$\omega_{r}$, p.u. & $k_{11}$ & $k_{22}$ \\
\hline 0 & 0.444 & 0.407 \\
\hline 0.1 & 0.595 & 0.032 \\
\hline 0.2 & 0.617 & 0.0097 \\
\hline 0.3 & 0.622 & 0.0054 \\
\hline 0.4 & 0.623 & 0.0039 \\
\hline 0.5 & 0.624 & 0.0032 \\
\hline 0.6 & 0.624 & 0.0028 \\
\hline 0.7 & 0.624 & 0.0026 \\
\hline 0.8 & 0.625 & 0.00244 \\
\hline 0.9 & 0.625 & 0.00234 \\
\hline$\omega_{\text {r.rat }}$ & 0.625 & 0.00226 \\
\hline 1.1 & 0.625 & 0.00221 \\
\hline
\end{tabular}

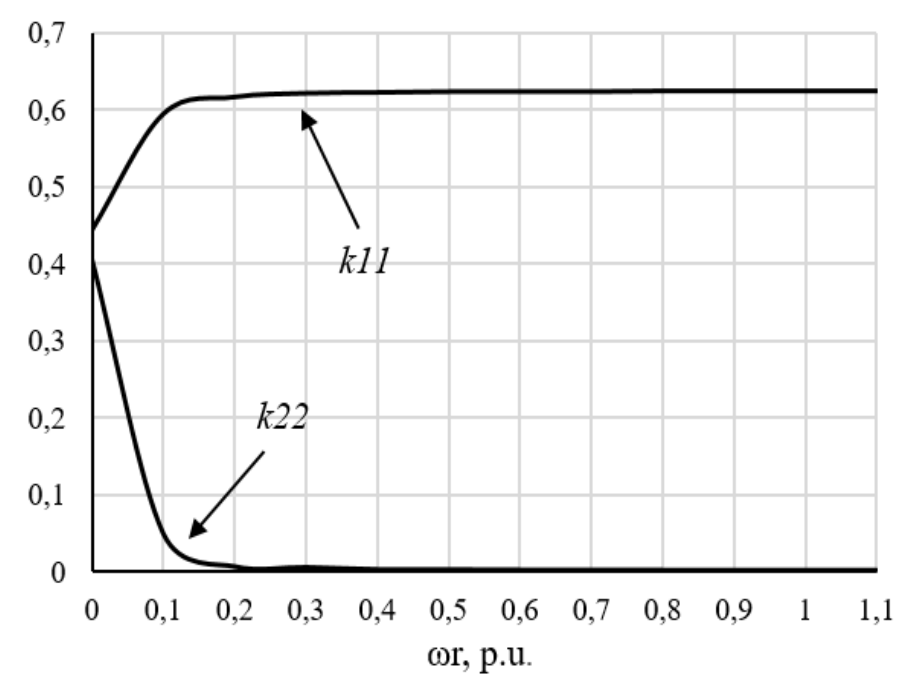

Fig. 2. Dependencies of coefficients $k_{11}, k_{22}$ on angular rotation rate of the rotor $\omega_{r}$ 
a)

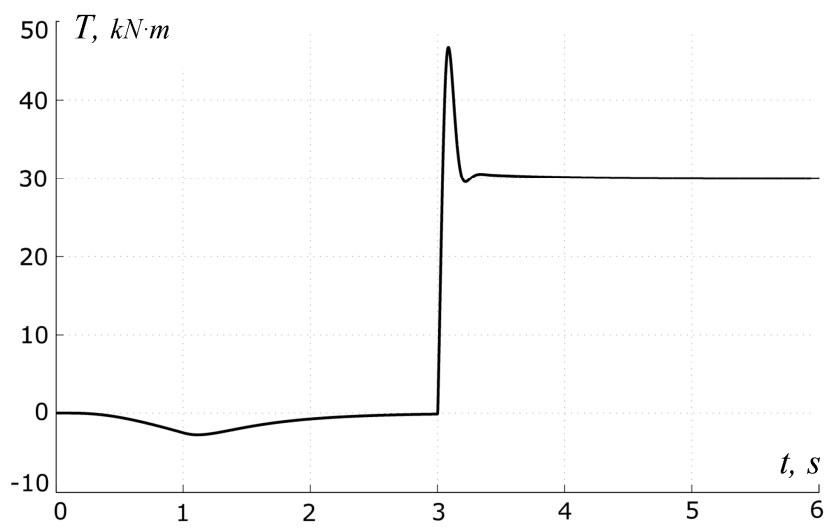

b) $\quad 115, \omega, \mathrm{rad} / \mathrm{s}$

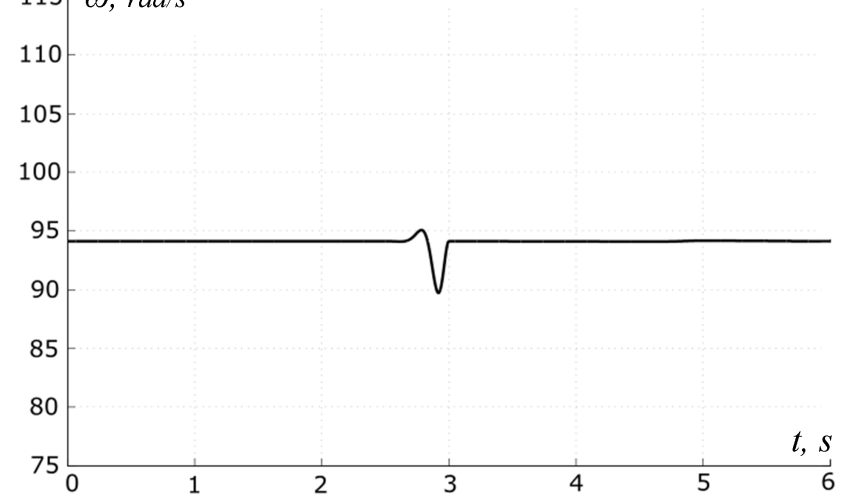

c)

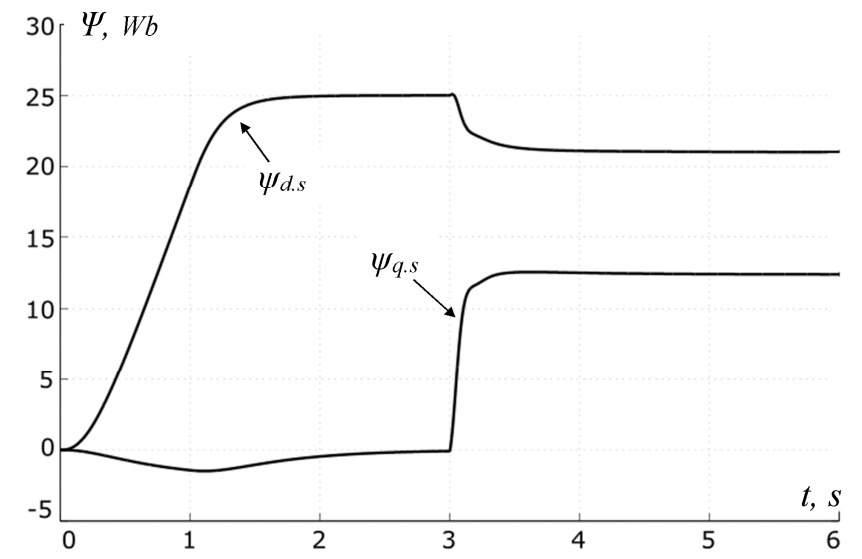

d)

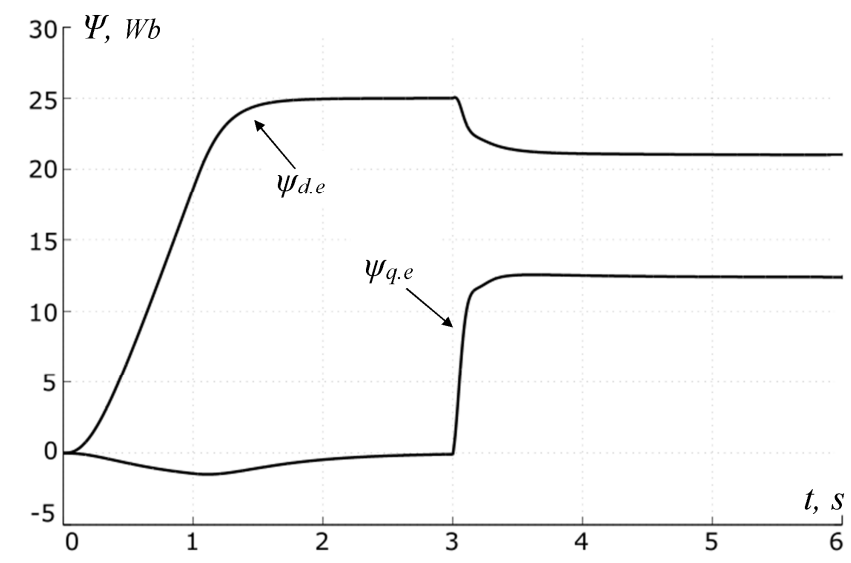

Fig. 3. Curves of changing torque (a), rotation rate (b), projections of stator flux linkage: design (c) and supplied by the state observer (d) 
a)

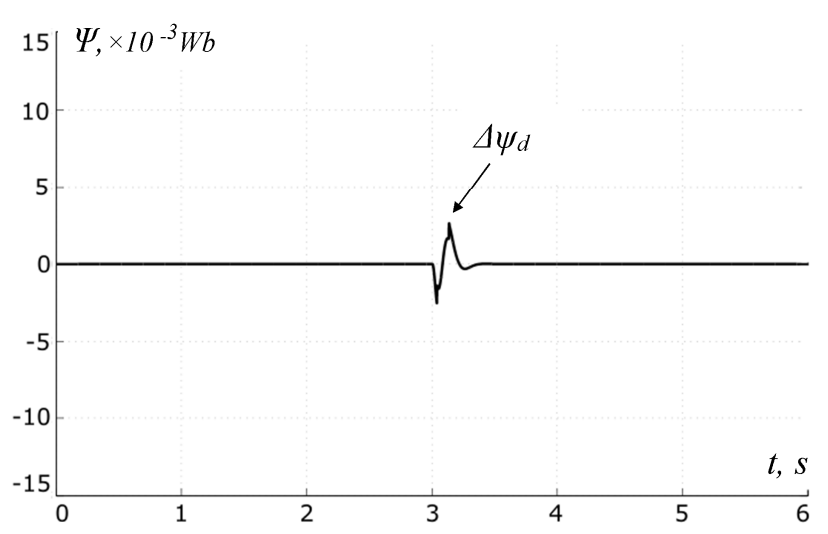

b)

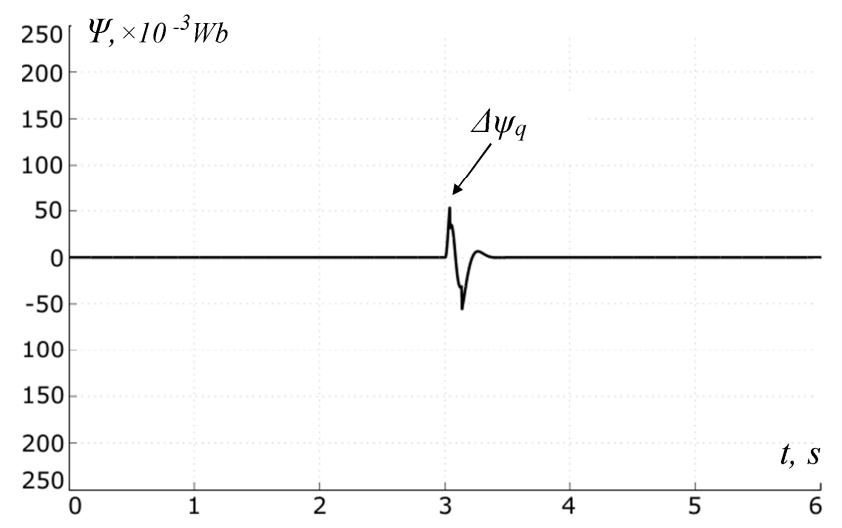

Fig. 4. Observer error

are shown in Fig. 3, a, b), where $\psi_{d . s}$ and $\psi_{q . s}-$ projections of flux linkages calculated with the known formulas (Fig. 3, c), $\psi_{\text {d.e }}$ and $\psi_{\text {q.e }}-$ projections of flux linkages supplied by the state observer (Fig. 3, d). Fig. 4 shows error of the observer: $\Delta \psi_{d}=\psi_{\text {d.e }}-\psi_{\text {d.s }}$ and $\Delta \psi_{q}=\psi_{q . e}-\psi_{q . s}, \mathrm{~Wb}$, its relative value does not exceed $0.15 \%$. Such a high accuracy may be explained by the fact that parameters in the state observer complied with those of the SM model during modeling.

\section{Conclusions}

The paper highlights main principles of designing up-to-date systems based on the vector method of generating electromagnetic torque of the variable frequency synchronous electric drive of the rolling mill.

The authors offer the design of observer of magnetic flux linkage state of the stator of synchronous motor based on the Luenberger observer with errorfeedback.

As exemplified in a real synchronous motor, calculation of observer parameters with high immunity is provided. Results of modeling transient processes at starting and shock loading SM of the rolling mill are offered.

\section{References}

1. Khramshin T.R., Kornilov G.P., Krubtsov D.S. et al. Ways to Improve the Stability of Electric Drives of Continuous Production with Brownouts. Bulletin of the South Ural St. Univ. Ser. Power Engineering, 2014, vol. 14, no. 2, pp. 80-87. (in Russ.)

2. Khramshin T.R., Krubtsov D.S., Kornilov G.P. Evaluation of Methods PWM Voltage Active Rectifiers Rolling Mills. Russian Internet Journal of Industrial Engineering, 2013, no. 2, pp. 48-53. (in Russ.)

3. Abdulveleev I.R., Khramshin T.R., Kornilov G.P. Analysis of Strategies of Modulation Voltage of the Active Front End Based on the Modular Multilevel Converters. Bulletin of the South Ural State University. Ser. Power Engineering, 2015, vol. 15, pp. 25-36. (in Russ.)

4. Böcker J., Janning J., Jebenstreit H. High Dynamic Control of a Three-Level Voltage-SourceConverter Drive for a Main Strip Mill. Ieee Transactions On Industrial Electronics, October 2002, vol. 49, no. 5, pp. 1081-1092. DOI: 10.1109/TIE.2002.803220

5. Mitronikas E.D., Safacas A.N. An Improved Sensorless Vector-Control Method for an Induction Motor Drive. Ieee Transactions on Industrial Electronics, December 2005, vol. 52, no. 6, pp. 1660 1668. DOI: 10.1109/TIE.2005.858706

6. Pan Y., Chen T. A High-Order Sliding Mode Stator Flux Observer for Asynchronous Motor Based on Feedback Linearization. 12th International Conference, Fuzzy Systems and Knowledge Discovery (FSKD), 2015, pp. 1514-1518. DOI: 10.1109/FSKD.2015.7382169

7. Trajin B., Regneir J., Faucher J. Detection of Bearing Faults in Asynchronous Motors Using Luenber- 
ger Speed Observer. 34th Annual Conference of IEEE "IECON 2008", Industrial Electronics, November 2008, pp. 3073-3078. DOI: 10.1109/IECON.2008.4758451

8. Dong X., Wang H., Wang J.A New Improved Method of Motor Speed Identification for Direct Toque Control of the Asynchronous Motor. International Conference on Electrical Machines and Systems, September 2005, vol. 1, pp. 68-71. DOI: 10.1109/ICEMS.2005.202486

9. West N.T., Lorenz R.D. Digital Implementation of Both a Stator and Rotor Flux Linkage Observer and Stator Current Observer. $42^{\text {nd }}$ IAS Annual Meeting. Industry Applications Conference Record of the 2007 IEEE, September 2007, pp. 1001-1007. DOI: 10.1109/07IAS.2007.155

10. Luenberger D.G. An Introduction to Observers. IEEE Transactions on Automatic Control, December 1971, vol. AC-16, no. 6, pp. 596-602. DOI: 10.1109/TAC.1971.1099826

11. Das S.P., Chattopadhyay A.K. ObserverBased Stator-Flux-Oriented Vector Control of Cycloconverter-Fed Synchronous Motor Drive. Ieee Transactions On Industry Applications, July/August 1997, vol. 33, no. 4, pp. 943-955. DOI: 10.1109/28.605736

Received 5 August 2016

\title{
СИНТЕЗ НАБЛЮДАТЕЛЯ СОСТОЯНИЯ ПОТОКОСЦЕПЛЕНИЯ СИНХРОННОГО ЭЛЕКТРОПРИВОДА ПРОКАТНОГО СТАНА
}

\author{
И.Р. Абдулвелеев, Т.Р. Храмшин, Г.П. Корнилов, А.А. Николаев \\ Магнитогорский государственный технический университет им. Г.И. Носова, \\ г. Магнитогорск
}

\begin{abstract}
Рассмотрен синтез системы управления частотно-регулируемого синхронного электропривода с векторным регулированием момента. Подобные приводы находят применение в механизмах с достаточно широким диапазоном скорости и ударным приложением нагрузки, например, станы горячей и холодной прокатки. Момент в рассматриваемых системах управления формируется двумя координатами: током и потокосцеплением статора. В данной статье произведен расчет параметров наблюдателя состояния потокосцепления магнитного поля статора синхронного двигателя с демпферными обмотками. Система реализована на базе наблюдателя Люенбергера с обратной связью по ошибке. Потокосцепление определяется в ортогональной системе координат $d, q$, синхронно вращающейся с ротором. Проведено моделирование комплекса, включающего синхронный двигатель с возбуждением и наблюдатель состояния. Результаты моделирования показывают, что относительная погрешность формирования потокосцепления не превышает $0,15 \%$.

Ключевые слова: наблюдатель состояния Люенбергера, потокосиепление статора, синхронный двигатель с демпферными обмотками, электропривод прокатных станов.
\end{abstract}

\footnotetext{
Литература

1. Способы повышения устойчивости электроприводов непрерывных производств при провалах напряжения / Т.Р. Храмиин, Г.П. Корнилов, Д.С. Крубиов и др. // Вестник ЮУрГУ. Серия «Энергетика».2014. - T. 14. - № 2. - C. 80-87.

2. Храмшин, Т.Р. Оценка методов ииротно-импульсной модуляции напряжения активных выпрямителей прокатных станов / Т.Р. Храмиин, Д.С. Крубиов, Г.П. Корнилов // Машиностроение: сетевой электронный научный журнал. - 2013. - № 2. - С. 48-52.

3. Абдулвелеев, И.Р. Анализ способов модулящии напряжения активных выпрямителей на базе модульных многоуровневых конвертеров / И.Р. Абдулвелеев, Т.Р. Храмшин, Г.П. Корнилов // Вестник ЮУрГУ. Серия «Энергетика». - 2015. - T. 15. - № 3. - C. 25-36.

4. Böcker, J. High Dynamic Control of a Three-Level Voltage-Source-Converter Drive for a Main Strip Mill । J. Böcker, J. Janning, H. Jebenstreit // Ieee Transactions On Industrial Electronics. - October 2002. - Vol. 49, no. 5. - P. 1081-1092. DOI: 10.1109/TIE.2002.803220

5. Mitronikas, E.D. An Improved Sensorless Vector-Control Method for an Induction Motor Drive / E.D. Mitronikas, A.N. Safacas // Ieee Transactions on Industrial Electronics. - December 2005. - Vol. 52, no. 6. P. 1660-1668. DOI: 10.1109/TIE.2005.858706
} 


\section{Электромеханические системы}

6. Pan, Y. Feedback Linearization / Y. Pan, T. Chen // 12th International Conference, Fuzzy Systems and Knowledge Discovery (FSKD). - 2015. - P. 1514-1518. DOI: 10.1109/FSKD.2015.7382169

7. Trajin, B. Detection of Bearing Faults in Asynchronous Motors Using Luenberger Speed Observer” / B. Trajin, J. Regneir, J. Faucher // 34th Annual Conference of IEEE "IECON 2008”, Industrial Electronics. November 2008. - P. 3073-3078. DOI: 10.1109/IECON.2008.4758451

8. X. Dong, H. Wang, and J.Wang, "A New Improved Method of Motor Speed Identification for Direct Toque Control of the Asynchronous Motor” / International Conference on Electrical Machines and Systems, September 2005, Vol. 1, pp. 68-71.DOI:10.1109/ICEMS.2005.202486

9. West, N.T. Digital Implementation of Both a Stator and Rotor Flux Linkage Observer and Stator Current Observer / N.T. West, R.D. Lorenz // 42 $2^{\text {nd }}$ IAS Annual Meeting. Industry Applications Conference Record of the 2007 IEEE. - September 2007. - P. 1001-1007. DOI: 10.1109/07IAS.2007.155

10. Luenberger, D.G. An Introduction to Observers / D.G. Luenberger // IEEE Transactions on Automatic Control. - December 1971. - Vol. AC-16, no. 6. - P. 596-602. DOI: 10.1109/TAC.1971.1099826

11. Das, S.P. Observer-Based Stator-Flux-Oriented Vector Control of Cycloconverter-Fed Synchronous Motor Drive / S.P. Das, A.K. Chattopadhyay // Ieee Transactions On Industry Applications. - July/August 1997. Vol. 33, no. 4. - P. 943-955. DOI: 10.1109/28.605736

Абдулвелеев Ильдар Равильевич, аспирант, старший преподаватель кафедры «Электроснабжение промышленных предприятий», Магнитогорский государственный технический университет им. Г.И. Носова, г. Магнитогорск; leggyild@mail.ru.

Храмшин Тимур Рифхатович, канд. техн. наук, доцент кафедры «Электроснабжение промышленных предприятий», Магнитогорский государственный технический университет им. Г.И. Носова, г. Магнитогорск.

Корнилов Геннадий Петрович, д-р техн. наук, профессор кафедры «Электроснабжение промышленных предприятий», Магнитогорский государственный технический университет им. Г.И. Носова, г. Магнитогорск

Николаев Александр Аркадьевич, канд. техн. наук, доцент, зав. кафедрой «Автоматизированный электропривод и мехатроника», Магнитогорский государственный технический университет им. Г.И. Носова, г. Магнитогорск.

Поступила в редакцию 5 августа 2016 2.

\section{ОБРАЗЕЦ ЦИТИРОВАНИЯ}

Design of Observer of Flux Linkage of Synchronous Drive of Rolling Mill / I.R. Abdulveleev, T.R. Khramshin, G.P. Kornilov, A.A. Nikolaev // Вестник ЮУрГУ. Серия «Энергетика». - 2016. - Т. 16, № 3. - С. 84-92. DOI: $10.14529 /$ power 160310

\section{FOR CITATION}

Abdulveleev I.R., Khramshin T.R., Kornilov G.P., Nikolaev A.A. Design of Observer of Flux Linkage of Synchronous Drive of Rolling Mill. Bulletin of the South Ural State University. Ser. Power Engineering, 2016, vol. 16, no. 3, pp. 84-92. DOI: 10.14529/power160310 